\title{
Media Literacy through photography and participation. A conceptual approach
}

\author{
Ángel V. Rabadán* \\ Department of Education, University of Huelva, Spain \{avrabadan@jccm.es\} (D) \\ Received on 12 July 2014; revised on 13 July 2014; accepted on 26 October 2014; published on 15 January 2015
}

DOI: $10.7821 /$ naer.2015.1.96

\begin{abstract}
We are living in social massification processes that oppress our identity and specificity as a human group; however, there are tools increasingly present among researchers, educators and other professionals who help to develop interpretations and create knowledge by developing a participatory communication perspective.

This article discusses how communication and learning through dialogue and creative practice can be fostered with social interaction and dialogic processes generated through participatory photography workshops, in order to contribute to media literacy. Similar to other creative experiences of this kind, this is not only a space to share products, jobs, tips and techniques, but also one for social interaction and communication. Educators in the field of media literacy can find, unprecedented challenges and opportunities in these initiatives to take advantage of the body of knowledge of adolescents and promote learning.
\end{abstract}

KEYWORDS: MEDIA LITERACY, PARTICIPATORY PHOTOGRAPHY, TEENAGER.

\section{INTRODUCTION}

The development of technological innovations is having profound changes in the economic, political, institutional and environmental field leading to the exploitation of resources and the most needed people, due to the enormous increase in what has been known as Technologies Information and Communication (Masterman, 1993). Processes of social mass that oppress our identity and specificity as a human group that creatively seeks his own alternative collective development as indicated by Pérez (2003, p. 9): "it is about new forms of social control mediated by particular consumption patterns predilection for certain lifestyles or divulgation of stereotyped speeches" and it is in schools, where it is further emphasized, as shown by the studies being conducted for more than twenty years (Buckingham, 2005)

Many of these issues are articulated in the mass media. This calls us to standardization and simplification of lifestyle, especially in their educational and cultural aspects that caused passive and submission / acceptance attitudes. These ideas

*To whom correspondence should be addressed:

Universidad de Huelva, Departamento de Educación

Facultad de Ciencias de la Educación. Campus de "El Carmen”

Avda. Tres de Marzo s/n - 21007 Huelva - Spain stigmatize and regard young people as problematic beings in the social imaginary sense, legitimizing certain myths and determining how important it is the way in which society, its various structures and the adult world in general relate to them. (Buckingham, 2005).

Researchers, scientists, educators discussed the concerns that appear when dealing with the media and technology in general; however "the media are not ends, and remains the essential problem of inter-human communication, the relationship between people" (Montero and Navarro, 2008, p.169) .

In this new digital society, which has created new forms of literacy, the 'ability to learn, to know what to do with what you learn emerges imminently because that capacity of "being socially unequal is linked to social family background, cultural level and education" (Castells, 2001). For this reason, we need to address literacy if we want to have competent world citizens throughout educational policies that incorporate new dimensions in their designs, "to account for the formation of a subject participating communicationally in the new possibilities" (Phillippi \& Avendaño, 2011) policies and practices. According to Aguaded (2005, p.29), "we are entering a new era of knowledge, visual thinking, and that means not only decentralize the modes of transmission and circulation of knowledge, but also that today constitute the decisive stage of socialization”.

It is required; therefore, to devise and design appealing and attractive spaces, participatory methodologies, and provide opportunities to implement a form of digital literacy sensitive to social and cultural representation. Participatory photography presented as such, with the intention of contributing to digital literacy and technologically helping youth to question representations and processes break otherness that as members of the educational community can also be expressed and integrated, to assert his voice.

\section{PHOTOGRAPHY AND PARTICIPATION}

Barthes understood that the images are not 'dumb' structures, nor for that matter, the recipients of the images, since these, as being typical of the culture and language, always tend to organize, interpret and mean what they see, what they live. In the set of such approaches, Barthes dwelves into the problems, recognizing and affirming that traditional methods of semiotics, as a resource for image analysis were limited, because beyond the inclusion of the receiver for a more complete analysis, it was necessary to go beyond the limits of classical semiotics, “(...) era model of the Standard, the Code, Act, or, if you prefer, of theology" (Barthes, 1986, p. 155). He held this idea in Camera Lucida reflection which emphasizes giving importance to the 
interaction between photography and the subject in the analysis of photografic images- by structuring two categories of access to the photographic image: the studium and punctum. For Barthes, it was relevant to transgress the strict limits of semiotic systems, through the punctum, offered an interpretive path for images, from the particular experience of the recipient of the photography. The photographic paradox formulated by Barthes is revealed as a key tool, inaugural, to address the issue of discursive power, instrument and ditch, in the context of participatory photography. The paradox, defined as the ability of photography to preserve its credibility as a record of a particular fact, and at the same time to present open polysemy as a surprise and the continued development of meanings, interpretations and speculations, showing the world: communicating.

Umberto Eco in 1997 claimed that "democratic civilization will be saved only if it makes the language of image provocation to critical reflection, not an invitation to hypnosis" (in Aguaded, 2012). In order to express an idea, an event to report, to show a communication, even in the particular sharing of an experience, the image is presented as a resource that articulates infinity of possible speeches.

This trend is shown in complex communication systems in which image takes precedence over any type of event, as it has been and is, the main substrate of the rhetoric of the media of mass communication, "it is usually forgotten that photography is the basis -gnoseologica and technological- of all forms of contemporary audiovisual expression and communication" (Marzal, 2007).

Consequently, it is recognized from a methodological point of view, as the use of participatory photography with a discursive potential, "rhetorical ability," and a communicative use of the photographic image. As Killion (2001, p 50) puts it: "a single photograph can contain thousands of references" and we are all capable of making interpretations and creating knowledge by developing a participatory communication perspective, based on dialogic relations for reflection, criticism and inter-subjectivity. In recent years, many studies attest to this, where participatory photography has become a popular tool among researchers, educators and other professionals, especially those working with vulnerable and marginalized groups, to promote social awareness and justice (Aldridge, 2012; Allen, 2012; DeJean, 2008; Guerrero \& Tinkler, 2010; Narayan, 2000; Radley, Hodgetts, \& Cullen, 2005; Wang, Cash, \& Powers, 2000; Ziller, 1990) and in different investigations as a tool for connecting with youth and adolescents: (Ali-Khan \& Siry, 2013; Checkoway \& Richards-Schuster, 2004; Coronel \& Rodríguez, 2013; Hubbard, 1991; Luttrell, 2010; Mizen, 2005; Mizen \& Ofosukusi, 2010; Sharples, Davison, Thomas, \& Rudman, 2003; Skovdal, 2011; Rabadán, 2014) among others.

Projects, in which the idea is to produce and transmit a shared, participatory work, where everybody identifies themselves with the project and can attain common goals (Moon, 2009; Luttrell, 2010; Mizen \& Ofosukusi, 2010; Guerrero \& Tinkler, 2010; DeJean, 2008; Allen, 2012; Ali-Khan \& Siry, 2013; Aldridge, 2012 Colonel \& Rodriguez, 2013; Rabadán, 2014), whose central focus is on the integral development of students. In addition, in relation to the practice of photography itself, the coveted intentions of the issuer can also be included. And these intentions expressed values and ideologies of a particular social situation. The latter leads us to the conclusion that photography is a construction that combines and clarifies conventions and particularites and therefore produces a kind of "imbued with meaning" image, caused by the aspiration of producing some speech, an utterance and enunciation. A construction, which calls necessarily to action, interrelation between self-awareness and action; a "permanent and constant dynamic of our attitude toward culture itself” (Freire, 1975, p. 5)

Therefore, when establishing an immersion in this field, the one on participatory photography, we believe it is necessary to maintain a diatopical look, a thoughtful reflection that builds on the one hand, the rise of social practices from implementing that will; and on the other hand, to analyze the process by which the field is being built by the Academy.

With regard to social practices, analyze the ways in which it is incorporated and reflect on the communication issues in the field of organizations and social movements, considering the social context (events, mobilization cycles with connecting work of these social organizations...). And as far as the Academy is concerned, it is of paramount importance to review the processes of theorizing carried out by researchers, universities and reflection centers linked to the field.

However, considering the standardization of media communication practices based on cultural stereotypes that permeate and therefore literate world from repetitive issuance of securities, would it not be necessary to reconsider this issue and through participatory photography as a methodology, inquire for literacy and media attention to help build citizenship in accordance to the times?

\section{THE "OTHER" PARTICIPATORY PHOTOGRAPHY}

To talk about participatory photography leads us, initially, to be within nonprofit organizations, cooperation and development agencies, freelance photographers who work with vulnerable groups and / or at risk of social exclusion across the globe, generally in communication projects for social change and development: Photovoice in England, Asha Nepal, and Bridges to Undesrtanding Click on Hearts in the US, Guatemala Photo Kids, Aecha Paraguay, Photovoice Singapore, and in Spain, organizations such as Picture Action Photovoice and youPHOTO.

Nonetheless, today we witness other participatory events through photography, where images are shared and speeches are pretended. We do not refer only to internet platforms like Flickr, Picasa, Instagram, 500px, Pinterest, etc. But also to those constant transactions, which are made through instant messaging: SMS, Whatsapp, Telegram, Teleline, etc. In the era of convergence, new possibilities of generating symbolic proposals that reflect the experience of the subjects themselves are shown, developing communication products [such as photographs] that "form and substance" express their particular views, sensations, comprising feelings and ideas to be shared. What is relevant is that these expressions can be shared not only at local / national level, but in spaces and communication experiences beyond their everyday territories, which Sinclair (2000) calls "geolinguistic regions". The subjects are likely to receive and generate proposals for meaning, from the use of devices infocomunicativo system, being able to generate "stories" or "micro-stories" that link them to concerns and issues that involve their own experience as the other ones. As Castells (2009, p 395) points out, "the public space is the space of social and meaningful interaction, where ideas and values are formed, 
transmitted, are backed up and struggled; space that ultimately became the training ground for action and reaction.».

This puts them in a symbolic communicative practicescultural plane in which individuals use technological devices as a form of symbolic power (Lull, 2000), but with a central distinction; it is no longer just about construct meanings from images and their viewing / reading is not only to express by express. It implies telling from itself in a space where "otherness" is included, to express to others. These symbolic spaces "conversation" are obviously different in nature, ranging from the 'issues' given by the media to the problems of the neighborhood, from the perception of the environment to the precariousness of employment, from reviews of the educational system to the very affective experiences. Nonetheless, in all these planes it is not only necessary to have the appropriate devices or "experience" from which "to tell” us if enough digital competence is needed, as well as to possess a certain cultural capital (Bourdieu , 1997).

It is certain the applications made by the subjects, require access, it is also important to manage basic elements of digital competence, but it is especially important to have built a sense of Internet use, ie: the pretext that set subjects to relate their own biography (domiciled socioculturally) to certain uses.

Now, what happens in these events in the photography and participation? Perhaps it is because it is incurring risks. The above is supported by Bauman (2002, p. 37) when he says that social processes of this liquid modernity are tending to "transform human identity of something given within a task, and making actors accountable for performing this task and the consequences (as well as side effects) of their performance "without liability. To work literacy through participatory photography, must be understood as a proposal addressed to "empower communicationally" aiming at looking to collecting new challenges posed by changes in individuals, social processes and new devices and grammars that are included the new and old media, to understand the transition of identity to identities in ever changing and fluid social contexts. (Touraine, 2005)

A participatory photography as socio-communicative space, in which subjectivity, society, critical analysis and expression are hybridized, which also pose a methodological approach that involves and implies learning how to collect and report the new social context to the communication technologies available for helping the subject to tell stories about him/herself and collectively. Thus, it is considered that other participatory photography and literacy framed in three dimensions from which this educommunicative perspective is defined and constructed: 1. To be generated from citizens and civil society, due to its communicative potential; 2. To be Oriented towards the development of narrative skills of individuals, encouraging the expressive abilities to construct stories, associated with a certain cultural capital. Narrative skills involving critical and reflective capacity, but not only mediated communication but the social context of the subjects; 3 . And seeking participation between subjects to organize themselves based on common goals or new social movements converged in communication realities and opportunities for social participation.

\section{MEDIA LITERACY AND COMMUNICATION}

\subsection{Media Literacy}

Although there are many difficulties to conceptually frame the term media literacy and terms related to the teaching of the media, it is an exercise, which is constantly being constructed (Contreras, 2014); according to Gutiérrez and Tyner (2012, p 34) "since Gilster (1997) popularized the concept of 'digital literacy' (Digital Literacy) many terms for this basic preparation for the digital society have appeared: multiliteracies (multiliteracies) (Cope \& Kalantzis, 2000; Cope \& Kalantzis, 2009; Jenkins \& al., 2006; Kress, 2000; Robinson, 2010); media literacy (Media Literacy) (The New Media Consortion, 2005); New Literacies (New Literacies) (Dussel, 2010; Jenkins \& al., 2006); MIL (Media and Information Literacy) UNESCO (2008, p. 6); media literacy education (Media Literacy Education).

In the plethora of terms and concepts, "there is an urgent need to sharpen and focus the energy arguments, given the risk that media literacy is dispersed in the mist of technological rhetoric. Another possible risk is falling into extreme and widespread, illdefined ambiguity. Something like a set of good intentions, but insufficient in practice "(Buckingham, 2010, Mc-Dougal \& Kendal, 2012, p. 22). Therefore, you should also consider the critical formation of citizens in economic, cultural, and social equality and the advancement of citizenship environment (Area \& al., 2012, p. 28).

We are still in a model marked by a technological discourse about changes in society 'full of rhetoric, promises and forced hopes "as claimed by Pérez-Tornero and Varis (2010, p. 14) and "maybe we are not prepared to explain fully (...) because it affects all dimensions of our existence. Perhaps, this is an unprecedented change, which affects not only our environment, but also decisively influences our psyche and our character. Perhaps "it is now imperative to abandon the blind trust in technology, striving to deepen our critical spirit. We must develop a conscious attitude” (Turner \& Varis 2010, p. 14). Humanizing communication processes from a perspective that understands the importance of ideological action between individuals and placed back in thinking people, not machines. This could be the approach that is expected to result after the technological mirage to which the company is exposed in recent times (Contreras, 2014). A time in which, as Mari Saez (2011, p. 10) states, prevails with technological determinism, which is at the center of analysis and solutions for information technology and communication, addressing the economic, social or political factors, which have not been addressed or directly made to fade away.

Accordingly, in this technological mirage to which we refer, Contreras (2014) describes as "trickster" or on peripheral devices' "authentic prosthesis of our bodies" (Pérez-Tornero, 2012) has generated and continues to generate imperatives with which adolescents could not live without. In this age of media convergence, "where old and new media (...) collide, convergence does not occur with sophisticated media devices. Convergence occurs; however, within the individual brains of consumers through their social interactions with others" (Jenkins, 2008, p. 14). Although we confront new paradigms in communication, the traditional paradigms have no relevance today. Kaplún stated that citizens and especially teenagers "feel the need and demand the right to participate, to be actors, in the construction of the new truly democratic society as they demand justice, equality, the right to health, right to education, etc., as well as to claim their right to participation, and to communication” (Kaplún, 1998, p. 3).

The initiatives for media education, understood as the formation process whose realization is media literacy (Buckingham, 2005, p. 21), necessarily presuppose certain axiological speech referents (ethical, political and civic). 
"Educating for media citizenship is reciprocally as a way of empowering citizens in pluralistic, democratic and hipercommunicative societies" (Gonzalez \& Contreras, 2014, p. 135 ), where the process is more important than the product. Strengthening collective processes that precede the development of messages and prevail over the activities of design, production and dissemination. The process extends over a period that has a beginning, but no immediate end because neither begins nor ends with the messages. Organizational strengthening, the recovery of memory and collective identity, yet ultimately, the growth of democratic life are the real results of the communication process.

In the new media environment and the establishment of what has been called the era of the prosumer, media education should be capital and equitable for all citizens, because as I said, Kaplun (1998, p. 51) "only participating, engaging researching, asking questions and seeking answers, and discussing is what actually becomes knowledge. You learn really what we live, what is recreated, what is claimed and what is simply not seen, read or heard. Only when there is a real learning process there; and when there is self-management of learners."

"When we do educational communication [through participatory photography] we are always looking, in one way or another, for a training result. We say that we produce our messages [through photographs and dialogic processes] which recipients use to become aware of their reality, or to provoke reflection or to generate a discussion” points Kaplun (1998, p.17).

\subsection{Dimensions and indicators: media literacy}

Ferres and Piscitelli (2012) offer some criteria that should govern media education, plus an articulated proposal of dimensions and indicators to define the new media competition. This proposal has been made by the authors and adjusted to reflect the contributions from 50 leading experts, Spaniards and foreigners alike through research challenges in visual communication: articulated proposal dimensions and indicators. Thus, the document states that "the media competence involves mastery of knowledge, skills and attitudes related to six basic dimensions of leading indicators that will serve as a basis for assessing the degree of competition, audio-visually speaking. These indicators relate, as appropriate, with the scope of participation as recipients messages and interact with them (field analysis) and as people who produce messages (level of expression)" (Ferrés \& Piscitelli, 2012). And although it is a significant proposal, their detractors Perez and Delgado (2012), after analyzing and studying the latest research refer proposals of indicators to assess levels of media competence, manifest that "the development of media literacy involves a conceptualization [perhaps] wider in relation to domain concepts, procedures and attitudes to express and understand the communication in any type of media or technological support” (Delgado \& Pérez, 2012, p. 33). It is a fact the rapid changes lead us to constantly expand the fields of action of these initiatives.

Also, it is understood that learning to propose actions based on an instructional design of the same "will serve the process convenient access and search for information, to the different languages which encode messages of our time at the reception and understanding thereof, to technology that disseminates and supports, production, politics and ideology of the media industries, to citizen participation and creative side. Thus, people get autonomous and critical when dealing with the media and information technology and communication” (Delgado \& Pérez, 2012, p. 33).

All these dimensions and indicators have helped develop working tools of different kinds: interviews, questionnaires, focus groups, workshops, etc. that are being used right now to not only evaluate children, teens, seniors, teachers, etc. the field of formal education, but also look at putting other groups, such as communication professionals, college students, families and vulnerable groups and / or at risk of social exclusion. Considering the above, we understand that developing tools that are appropriate to the contexts and references for each of these groups and practices codes, you can get a more comprehensive view of the level of literacy and media competence and the importance of acquiring skills necessary to not only fend optimally, but also to exercise our rights and responsibilities as citizens, "The development of media competence to strengthen citizens” (Contreras, 2014, p.49).

Analyze how media-literate with participatory photography as a communicative practice it could be a recurring exercise, however, in turn can also help to analyze the practice itself.

\subsection{Selection and proposed indicators for media literacy through participatory photography}

From the research cited in this impactful and landmark article, published in the last decade with international recognition, by Perez and Delgado (2012) in which actions-based learning to instructional design in the development of literacy media is proposed; with a broader conceptualization in relation to the domain of concepts, procedures and attitudes to communication and understanding towards participatory photography; a selection of indicators are offered which are considered relevant in six dimensions hinged together, from awareness by part of the subject to shoot it [autonomy that has to execute the act] and process in your practice, as a person who thinks and acts inserted from his/her own being and to be the center of action, reflection and power.

\subsubsection{Access to information}

Dimension: Ideology and values

(1) Scope of analysis:

Recognize the influence of media messages on decisions and personal relationships, family, etc.

Identify goals / interests underlying media productions on: ideology, explicit and latent values.

Ethics inquiry into useful products, information or entertainment attitude.

Ability to analyze and detect virtual identities stereotypes, analyzing its causes and consequences.

Manage emotions in interaction with screens, depending on the ideology and values transmitted.

(2) Scope of expresion:

Use new communication tools according to civic, democratic and social values and natural respect.

Develop and modify existing products to question values or stereotypes in media productions.

Take advantage of tools of the communicative environment responsibly within an intercultural dialogue. 


\subsubsection{Visual and dialogic language. Coding and decoding}

Dimension: Languages

(1) Scope of analysis:

Interpret and evaluate codes of representation and the role they play in a message.

Analyze and evaluate messages from the meaning, sense, narrative structures, genres and formats.

Understand the flow of information from multiple media, supports, platforms and means of expression.

(2) Scope of expresion:

Express itself through a wide range of systems of representation and meaning.

Choose different representation systems and styles depending on the content to be transmitted and interlocutor.

\subsubsection{Reception and understanding of the message}

Dimension: Reception processes and interaction

(1) Scope of analysis:

Assess the cognitive effects of emotions, awareness of ideas and values.

Know the importance of context in the reception and interaction.

Appreciate messages from other cultures to intercultural dialogue.

(2) Scope of expresion:

Active attitude with screens to build a citizenry able to transform themselves and the environment

Conduct a collaborative work by creating connectivity and social networking platforms.

Know the legal rules in audiovisual and attitude response.

\subsubsection{Technology that supports and disseminates}

\section{Dimension: Technology}

(1) Scope of analysis:

Understand the value of information technology and communication and their potential effects.

Interact meaningfully with means which allow to expand mental abilities.

Curious attitude motivated to learn and use communication technology innovations.

(2) Scope of expresion:

Select, review and self-assess their own media diet, based on conscious and reasonable criteria.

Adapt technology tools to communicative objectives pursued.

Develop and manipulate images knowing the construction of representations of reality.

\subsubsection{Production and distribution}

Dimension: Production and distribution processes

(1) Scope of analysis:

Differentiate between individual and collective productions, popular and corporate, public and private.
Meet production systems, programming techniques and mechanisms of diffusion.

Understand the self-regulatory codes that protect and require different stakeholders.

(2) Scope of expresion:

Working collaboratively in the development of photographic and media projects.

Select meaningful messages, appropriate them and transform them with new meanings.

Share and disseminate information through traditional media and social networks.

Manage the online / offline own identity and responsible attitude to the data control themselves and others.

\subsubsection{Creative participation. Aesthetics}

Dimension: Aesthetics

(1) Scope of analysis:

Cultivate taste for formal aspects, not only what you communicate, but also the way they communicate.

Recognize a media production that will not fit into the minimum requirements of aesthetic quality.

Relate media productions with other art forms, identifying mutual influences.

Identify the basic aesthetic categories such as formal and thematic innovation, originality, style, schools and trends.

(2) Scope of expresion:

Produce basic messages that are understandable and that help increase personal and collective creativity, originality and sensitivity levels.

Transform and appropriate artistic productions, enhancing creativity, innovation, experimentation and aesthetic sensibility.

\subsection{Cultural and Visual Creativity. Action Strategies}

Returning to Castells, through his work the information age and network society where he studied the changes occurring in production, in power, in culture, in social relations and modes of existence; stated that these processes had created a new ruling structure; a new economy, information / global; and a new culture, the culture of real virtuality (Castells, 1997, p. 371). A real through the screens that makes us perceive the world in a unique way, with an overwhelming presence of images in the current perceptual universe of potential images and direct existential connection between the subject and object virtuality.

Nevertheless, this new network culture should not discard that other visual culture, not only that slavishly reproduce the visual appearance, as they are perceived by our eyes generalizing any idea of photography, or presented on a screen, but also include any other idea or visualization. The content of an expanded visual culture is displayed on three different processes: the process of seeing the world; the process of making visual representations of the world; and the process of imagining and creating mental images of the world (Mitchell, 2005, p. 239). That is, in this network society we continue to look, visualizing and imagining the world and these three forms of visuality should be the basis of any strategy for action. 
And although "the picture before us asserts the existence of that which it represents" (Dubois, 1986, p.50) the picture would be understood in a more "extended" way, while the common task of all sciences, consistent primarily to record, produce, analyze and interpret indications of reality. In his later years, Roland Barthes wrote "that beyond the informational / communicative and referential symbolism, diegetic, authorial or historical level, there is (...) a third meaning split with significant ownership of representation” (Villaró I Moncasi, 2011). Paradoxically, Berguer points out that when a photograph is also used with words together can produce an effect of unquestionable certainty or even dogmatic assertion (Berguer, 2008, pp.91-92) of power, as in the dialogic processes towards participatory photography.

In any case, go blind to the reality of substantial and instrumental images would give the project a multimodal social science in which new ontological, epistemological, methodological and technical perspectives (Bericat, 2011) are integrated. The best strategy undoubtedly is a media education which has to be raised to be a starting point for alternative movements emerge where at least they can think about their reality, appropriate the resources to understand and develop the scientific, moral and social budgets that allow to recreate. Something told Aguaded (2004, p. 27) that "the challenge of audiovisual society is simply to integrate media in education to reflect on themselves, their languages, their ways of reporting on the world and its powerful weapons to recreate and build it.”

Perhaps we should return to Habermas (1987) and his theory of social action on the basis of human communication, and discourse ethics: procedural, universal and constructivist, and trust in the ability of people to direct the course of events.

\section{EMPOWERMENT: THE VOICE OF THE IMAGE}

Now, when appealing to the term of empowerment, from the communicative and specifically the Communication and Education perspectives, we will need to constantly review the different conceptualizations. However, despite the differences in trying to round-off the end, as it appears, its purpose is to help make proposals that contribute to the formation of critical, conscious and narrative skills in responsible citizens and for civic use, thus promoting participatory and deliberative processes that sustain a living that allows citizens to participate in both individual and collective infocomunicative public spaces. (Gonzalez, 2011; Phillippi \& Avendaño, 2012) (Gonzalez \& Contreras, 2014)

Thus, Gonzalez and Contreras (2014) state that the concept of empowerment, should put us on two main approaches to understand -such as Dialogic ethics and the capability approach; for their involvement with the communication field and for their contribution to the notion of human development present in media education programs of international organizations such as UNESCO and the European Commission; and the failure to understand the participatory photography if not linked to the dialogic critical pedagogy of Paulo Freire, as part of their pedagogy of the question that is of clearly political and practical guidance. Understanding thence participatory photography involves taking [and rescuing] three aspects: a) First, the individual ceases to be a mere object, it is no longer a vacuum to-be-filled container, but, as a subject, which will be subject to challenge to achieve a critical understanding of their situation as an active subject of praxis and transformative social reality. b) In turn, the object of study must be enrolled in the liberating educational practice and part of it considered for analysis, so that it would be a political act of knowledge. c) As for the method, there is something already established or imposed, but is cocreated and re-created with the subjects participating in the act of creation of contextualized and historicized knowledge (Escobar, 1990; Freire 2002a, 2002b;).

Experimenting through participatory photography as a tool edu-communication can not be understood without its civic purpose without ethical, social and democratic background related to the empowerment of citizens, and thus adolescents (Coad \& Evans, 2008). We agree with Gonzalez and Contreras (2014) empowering means strengthening autonomy, participation and freedom, through their narratives, their dialogues and speeches for human development and freedom at large. Open space of intersubjectivity, through photography and participation, a consensus seeking truth, justice and social progress (Habermas, 1987). The truth, understood as unbreakable bond between action and reflection, dialogic processes about reality, the correction in the dialogue about justice, liberty when equality or symmetry are enunciated and interpreted among participants and about the truth or sincerity in the communication process (in Gonzalez \& Contreras, 2014) that can change the world.

Regarding the capability approach, it appears that the new technological devices and new grammars are used by teens as they take on a meaning in their everyday practices and life stories. In addition, both children and adolescents have been very important in the consolidation and understanding of the changes at the cultural level and not just in the communicative area. They are, in many cases, leading the way in the adoption of broader social innovations. As stated, by Mead (1971), an ethereal younger group producing their own symbolic-cultural systems had been generated for decades, even without fully considering the proposals of the traditional agencies of socialization such as the family and school. It is possible that in this new century, characterized by the speed of change, the youth and children are precisely what typify many symbolic proposals. By using the photograph turned into a highly flexible cultural tool and language barriers to suit all abilities can be bridged. The language that is born from the images gives a creative and different perspective to convey ideas and feelings. The photographs that make up the "looks" become useful tools, an excellent way to define situations, and communicate different perspectives to raise awareness of what surrounds us. Its ease of dissemination promotes exchange and increases the potential for dialogue and debate, contributing to decision-making related to this ecosystem.

This, in turn provides a space for confidence and expression, but above all, it avails a new way to observe and recognize (Rabadán, 2014). A process both individually and collectively; both interpersonal and communal (Hur, 2006), which empowers us in relation to what we think of ourselves: through the awareness of our abilities and knowledge of our potential (Staples, 1990, p. 32). And in this strict relation to individual empowerment, individuals unite to break their own solitude and silence, mutually interacting and learning from each other, developing tools for collective action (Boehm \& Staples, 2004). In the transition from awareness to action, the individual becomes aware of his/her power, becomes empowered, acting to help improve their situation and that of the community. 
Perhaps we should not expect "the existence of individual discomfort and / or social unrest as the first step to empowerment" (Hur, 2006, p. 529), perhaps the adventurers in this case, are lost and walk confusedly without finding the exit. It is necessary, therefore, to generate new concepts that allow new training on methodological guidance, communication and education to promote the use of new emerging digital spaces as empowered citizens communicatively, i.e competent to tell (expressive skills) more specifically recounted (as individual) and tell us (collectively), brought about by the converging elements of digital technology because knowledge is constructed culturally and meanings change over time and from place to place.

\section{CONCLUSION}

In this paper, we have analyzed the relevant theoretical link between the practice of photography and participation, media literacy and the key to empowerment, which has led us to make a proposal that integrates dimensions and measures, in our view for the development of media competence in order to construct a valid rationale for media education through participatory photography. An opportunity for the expansion and enrichment of the field as well as the social practices of appropriation and transformation being carried out in the last decade; the experience and the construction of social and human reality.

In fact, our findings can be used to build on these ideas and argue with image-based research the purpose of contributing to digital literacy and technologically by helping youngsters and adolescents to question representations and to break processes of otherness that as community members also can express and integrate. Through social interaction and dialogic processes can promote intercultural understanding and learning through dialogue and creative practice, teaching literacy in the new digital era.

After all, technology a means to educate the media and the general public must be seen as way to empower them. We suggest that this type of work can contribute specifically to the knowledge base of teachers, educators, trainers and practitioners as they consider the visual methods as a means of good teaching (Kincheloe, 2003) as well as a continuous and complex research praxis, passing between the visual and the verbal; the theoretical and the empirical; documented processes and interpretations, we seek to weave a complex series of perspectives and understandings.

\section{REFERENCES}

Aguaded, J. I. (2005). Estrategias de edu-comunicación en la sociedad audiovisual. Comunicar, 24, 25-34.

Aguaded, J. I. (2012). La competencia mediática, una acción educativa inaplazable. Comunicar, 39, 7-8. doi: 10.3916/C39-2012-01-01

Aldridge, J. (2012). The participation of vulnerable children in photographic research. Visual Studies, 27 (1), 48-58. doi: 10.1080/1472586X.2012.642957

Ali-Khan, C., \& Siry, C. (2013). Sharing seeing: Exploring photo-elicitation with children in two different cultural contexts. Teaching and Teacher Education, 37, 194-207. doi: 10.1016/j.tate.2013.08.004

Allen, Q. (2012). Photographs and stories: ethics, benefits and dilemmas of using participant photography with Black middle-class male youth. Qualitative Research, 12(4), 443-458. doi: 10.1177/1468794111433088

Area, M., \& Guarro, A. (2012). La alfabetización informacional y digital: fundamentos pedagógicos para la enseñanza y el aprendizaje competente. Revista española de Documentación Científica, 35, 46-74. doi: 10.3989/redc.2012.mono.977

Barthes, R. (1986). Retórica de la imagen Lo obvio y lo obtuso: Imágenes, voces, textos. Buenos Aires: Paidós.

Bauman, Z (2000). Liquid modernity. Londres: Polity Press.

Berguer, J. (2008). Otra manera de contar. Barcelona: Gustavo Gil.
Bericat Alastuey, E. (2011). Imagen y conocimiento: retos epistemológicos de la sociología visual. Empiria. Revista de metodología de ciencias sociales, 22, 113-140. doi: 10.5944/empiria.22.2011.87

Boehm, A., \& Staples, L. H. (2004). Empowerment: The point of view of consumer. Families in Society, 85(2), 270-280. doi: 10.1606/1044-3894.314

Bourdieu, P. (1997). Capital cultural, escuela y espacio social. México: Siglo XXI Buckingham, D. (2005). Educación en medios. Alfabetización, aprendizaje y cultura contemporánea. Barcelona: Paidós Ibérica.

Buckingham, D. (2011, June). Media Literacy: New Directions or Losing our Way? In Manifesto for Media Education Symposium. Symposium conducted at the meeting of the Royal Institute of British Architects, London.

Castells, M. (1997). La era de la información: economía, sociedad y cultura. Madrid: Alianza.

Castells, M. (2001). La Galaxia de internet. Reflexiones sobre Internet, empresa y sociedad. Madrid: Plaza y Janés. doi: 10.1007/978-3-322-89613-1

Castells, M. (2009). Comunicación y poder. Madrid: Alianza.

Coad, R., \& Evans, J. (2008). Reflections on practical approaches to involving children and young people in the data analysis process. Children and Society, 22(1), 41-52. doi: 10.1111/j.1099-0860.2006.00062.x

Contreras. P. (2014). La alfabetización mediática como herramienta de intervención en prisiones; Media literacy as a tool for intervention in prisons (Doctoral dissertation, Universidad de Huelva). Retrieved from http://hdl.handle.net/10272/7946

Cope, B., \& Kalantzis, M. (Eds.). (2000). Multiliteracies: Literacy learning and the design of social futures. London/New York: Psychology Press.

Cope, B., \& Kalantzis, M (2009). Multiliteracies: New Literacies, New Learning. Pedagogies. An International Journal, 4(3), 164-195. doi: 10.1080/15544800903076044

Coronel, J. M., \& Rodriguez, I. (2013). Let me put It another way: Methodological consideration son the use of participatory photography based on an experiment with teenagers in secondary schools. Qualitative Research in Education, 2(2), 98-129. doi: 10.4471/qre.2013.20

Chaplin, E. (1994). Sociology and visual representation. New York: Routledge. doi: $10.4324 / 9780203416723$

Checkoway, B., \& Richards-Schuster, K. (2004). Youth Participation in Evaluation and Research as a Way of Lifting New Voices. Children, Youth and Environments, 14(2): 84-98.

DeJean, W. (2008). Picture This: Using Photography to Conceptualize Social Justice.Multicultural Perspectives, 2(10), 105-109. doi: 10.1080/15210960801998021

Dubois, P. (1986). El acto fotográfico. De la representación a la recepción. Barcelona: Ediciones Paidós.

Dussel, I. (2010). Los nuevos alfabetismos en el siglo XXI: Desafíos para la selescuela. Retrieved from http://www.virtualeduca.info/Documentos/ve BA09\% 2-0_confDussel.pdf

Escobar, M. (1990). Educación alternativa, pedagogía de la pregunta y participación estudiantil. México: UNAM.

Ewald, W., \& Lightfoot, A. (2001). I wanna take me a picture: Teaching photography and writing to children. Boston: Beacon Press.

Ferrés, J., \& Piscitelli, A. (2012). La competencia mediática: Propuesta articulada de dimensiones e indicadores. Comunicar, 38(19), 75-82. doi: 10.3916/C382012-02-08

Ferrés I Prats, J., García Matilla, A., Aguaded, J. I., Fernández, J., Figueras, M., \& Blames, M. (2011). Competencia Mediática. Investigación sobre el grado de competencia de la ciudadanía en España. Instituto de Tecnologías Educativas, Consell de l'Audiovisual/Comunicar.

Freire, P. (1975). Acción cultural para la libertad. Buenos Aires: La Aurora.

Freire, P. (2002a). Pedagogía del oprimido. Madrid: Siglo XXI.

Freire, P. (2002b). La educación como práctica de la libertad. Madrid: Siglo XXI.

Gilster, P. (1997). Digital Literacy. New York: Wiley \& Sons, Inc.

Gozálvez, V., \& Contreras, P. (2014). Empoderar a la ciudadanía mediática desde la educomunicación. Comunicar, 42(21), 129-136. doi: 10.3916/C42-2014-12

Guerrero, A. L., \& Tinkler, T. (2010). Refugee and Displaced Youth Negotiating Imagined and Lived Identities in a Photography-Based Educational Project in the United States and Colombia. Anthropology \& Education Quarterly, 41(1), 55-74. doi: 10.1111/j.1548-1492.2010.01067.x

Gutiérrez Martín, A., \& Tyner, K. (2012). Educación para los medios, alfabetización mediática y competencia digital. Comunicar, 38(19), 31-39. doi: 10.3916/C38-2012-02-03

Jenkins, H. (2008). Convergente cultura: La convergencia de la cultura de los medios de comunicación. Barcelona: Paidós.

Habermans, J. (1987). Teoría de la acción comunicativa: Racionalidad de la acción y racionalización social (vol. 1). Madrid: Taurus.

Hubbard, J. (1991). Shooting back: A photographic view of life by homeless children. New York: New York Press. 
Hur, M. H. (2006). Empowerment in terms of Theoretical perspectives: Exploring a typology of the process and components Across disciplines. Journal of community psychology, 34(5), 523-540. doi: 10.1002/jcop.20113

Jenkins, H. (2006). Confronting the Challenges of Participatory Culture: Media Education for the 21st Century. Retrieved from the T. MacArthur Foundation website:

http://www.newm edialiteracies.org/files/working/NMLWhitePaper.pdf

Jenkins, H. (2008). Convergente cultura: La convergencia de la cultura de los medios de comunicación. Barcelona: Paidós

Kaplún, M. (1998). Una pedagogía de la comunicación. Madrid: De la Torre.

Killion, Ch. M. (2001). Understanding cultural aspects of health through photography. Nursing Outlook, 49, 50-54. doi: 10.1067/mno.2001.110011

Kincheloe, J. L. (2003). Critical ontology: Visions of selfhood and curriculum. Journal of Curriculum Theorizing, 19(1), 47-64.

Kress, G. (2000). Multimodality. In B. Cope \& M. Kalantzis (Eds.), Multimliteracies: Literacy Learning and the Design of Social Futures. London: Routledge

Kolb, B. (2008). Involving, sharing, analysing: Potential of the participatory photo interview! Forum Qualitative Sozialforschung / Forum: Qualitative Social Research, 9(3), Art. 12. Retrived from http://nbnresolving.de/urn:nbn:de:0114fqs0803127

Lemesianou, Ch. A., \& Grinberg, J. (2006). Doing educational research in a complex world. In K. Tobin \& J. Kincheloe (Eds.), Doing education research (pp. 211-234). Rotterdam, the Netherlands: Sense Publishers.

Lull, J. (2000). Media, Communication, Culture. A Global Approach (pp. 160188). New York: Columbia University Press.

Luna, J. R. (2009). Foto-etnografía llevada a cabo por personas en situación de pobreza en la frontera norte de México. Forum Qualitative Sozialforschung/Forum: Qualitative Social Research, 2, Art. 35.

Luttrel, W. (2006). Making culture visible: Children's photography, identity and agency. Paper presented at the Annual Meeting of the American Sociological Association, Montreal, Canada.

Luttrel, W. (2010). A camera is a big responsibility: a lens for analysing children's visual voices. Visual Studies, 25(3), 224-237. doi: 10.1080/1472586X.2010.523274

Luttrel, W., \& Chalfen, R. (2010). Lifting up voices of participatory visual research. Visual Studies, 25(3), 197-200. doi: 10.1080/1472586X.2010.523270

Lykes, M. B., Blanche, M.T., \& Hamber, B. (2003). Narrating survival and change in Guatemala and South Africa: The politics of representation and a liberatory community psychology. American Journal of Community Psychology, 31(1/2), 79-90. doi: 10.1023/A:1023074620506

McDougall, D. (2006). The corporeal image: Film, ethnography and the senses. Princeton: Princeton University Press.

McDougall, J., \& Kendall, A., (2012). Critical media literacy after the media. Communicar, 38, 21-29. doi: 10.3916/C38-2012-02-02

Marí-Sáez, V. M. (2011). Comunicar para transformar, transformar para comunicar. Tecnologías de la información desde una perspectiva de cambio social. Madrid: Editorial Popular.

Marzal Felici, J. (2007). Cómo se lee una fotografía. Interpretaciones de la mirada. Madrid: Cátedra.

Masterman, L. (1993) La enseñanza de los medios de comunicación. Madrid: Ediciones de la Torre.

Mead, M. (1987). Experiencias personales y científicas de una antropóloga. Barcelona: Paidós.

Mitchell, W. J. T. (2005). An Interview with W. J. T Mitchell. In M. Dikovitskaya (Ed.), Visual Culture: The Study of the Visual after the Cultural Turn (pp. 238257). Cambridge: Massachussetts Institute of Technology.

Mizen, P. (2005) A little “light work”? Children's images of their labour. Visual Studies, 20(2), 124-139. doi: 10.1080/14725860500244001

Mizen, P., \& Ofosu-Kusi, Y. (2010). Unofficial truths and everyday insights: understanding voice in visual reseach with the children of Accra's urban poor. Visual Studies, 25 (3), 55-267. doi: 10.1080/1472586X.2010.523278

Montero, M., \& Navarro, M. (2008). Comunicación y cambio social: algunos ejemplos históricos. Revista Comunicación y Hombre, 4, 169-177.

Narayan, D. (2000). La voz de los pobres: ¿Hay alguien que nos escuche? Madrid: Banco Mundial Ediciones Mundi-Prensa.

Packard, J. (2008). I'm gonna show you what it's really like out here': the power and limitation of participatory visual methods. Visual Studies, 23(1), 63-77. doi: 10.1080/14725860801908544

Pérez, M A., \& Delgado, A. (2012). De la competencia digital y audiovisual a la competencia mediática: dimensiones e indicadores. Comunicar, 39, 25-34. doi: 10.3916/C39-2012-02-02

Pérez, R. (2003). Psicología social de la comunicación de masas: Introducción a las teorías psicosociales de la recepción mediática. San José: Siedin.

Pérez-Tornero, J. M., \& Varis, T. (2010). Media Literacy and New Humanism. Paris: UNESCO: Institute for Information Technologies in Education.
Phillippi, A., \& Avedaño, C. (2011). Empoderamiento comunicacional: competencias narrativas de los sujetos. Comunicar, 36, 61-68. doi: 10.3916/C36-201102-06

Rabadán, Á. V. (2014). ҮоиРНОТО. “The voice of the image”. Fotografía participativa. Promoción de la convivencia y la identidad en un centro de enseñanza secundaria (Doctoral dissertation, Universidad Internacional de Andalucía). Retrieved from http://hdl.handle.net/10334/2834

Radley, A., Hodgetts, D., \& Cullen, A. (2005). Visualizing homelessness: A study on photography and estrangement. Journal of Community and Applied Psychology, 15(4), 273-295. doi: 10.1002/casp.825

Robinson, A. (2010). New Media Literacies by Design. In K. Tyner (Ed.), Media Literacy. New Agendas in Communication. New York/London: Routledge.

Sharples, M., Davison, L., Thomas, G. V., \& Rudman, P. D. (2003). Children as photographers: An analysis of children's photography behaviours and intentions at three age levels. Visual Communication, 2(3): 303-330. doi: 10.1177/14703572030023004

Sinclair, J. (2000). Televisión: comunicación global y regionalización. Barcelona: Gedisa.

Siry, C., \& Ali-Khan, C. (2011). Writing we: collaborative text in educational research. In C. Malott \& B. Portfilio (Eds.), Critical pedagogy in the 21st century (pp. 233-249). Connecticut: Information Age Publishing.

Skovdal, M. (2011). Picturing the coping strategies of caregiving children in Western Kenya: from images to action. American journal of public health, 101(3), 452-3. doi: 10.2105/AJPH.2010.192351

Staples, L. H. (1990). Powerful ideas about empowerment. Administration in Social Work, 14(2), 29-42. doi: 10.1300/J147v14n02_03

THE MEDIA CONSORTIUM (Ed.). (2005). A Global Imperative. The Report of the 21st Century Literacy Summit. California: New Media Consortium.

Tornero, J. P., \& Varis, T. (2010). Media literacy and new humanism. Unesco Institute for Information Technologies in Education.

Touraine, A. (2005). Un nuevo paradigma para comprender el mundo de hoy. Buenos Aires: Paidós.

UNESCO (2008). Teacher Training Curricula for Media and information Literacy. Report of the International Expert Group Meeting. Paris: International UNESCO.

Villaró Moncasí, A. (2011). El eco de la fotografía de Barthes. La nueva cámara lúcida: Notas sobre el cine digital. Comunicación y Sociedad, 24(1), 247-268.

Wang, C., Cash, J., \& Powers, L. (2000). Who knows the streets as well as the homeless? Promoting personal and community action through Photovoice. Health Promotion Practice, 7(1), 81-89. doi: 10.1177/152483990000100113

Ziller, R. (1990). Photographing the self. Newbury Park, CA: Sage. 